Connecting the Rule of Recognition and Intentionalist Interpretation: An Essay in Honor of Richard Kay

Larry Alexander

Follow this and additional works at: https://opencommons.uconn.edu/law_review

\section{Recommended Citation}

Alexander, Larry, "Connecting the Rule of Recognition and Intentionalist Interpretation: An Essay in Honor of Richard Kay" (2021). Connecticut Law Review. 494.

https://opencommons.uconn.edu/law_review/494 


\section{CONNECTICUT \\ LAW REVIEW}

VOLUME 52

APRIL 2021

NUMBER 5

\section{Essay}

Connecting the Rule of Recognition and Intentionalist Interpretation: An Essay in Honor of Richard Kay

\section{LARRY ALEXANDER}

In this piece, I take up two topics that have been preeminent in the scholarship of Richard Kay: the fundamental norm that is the foundation of legal systems, and the proper object of the interpretation of constitutional and statutory texts, namely, the texts' authors' intended meaning. My aim is to show how these two topics are related. 


\section{ESSAY CONTENTS}

INTRODUCTION 1515

I. KAY ON THE FOUNDATION OF LEGAL SYSTEMS.....................1516

II. KAY ON CONSTITUTIONAL INTERPRETATION..........................1521

III. CONNECTING THE PRECONSTITUTIONAL RULE WITH CONSTITUTIONAL INTERPRETATION

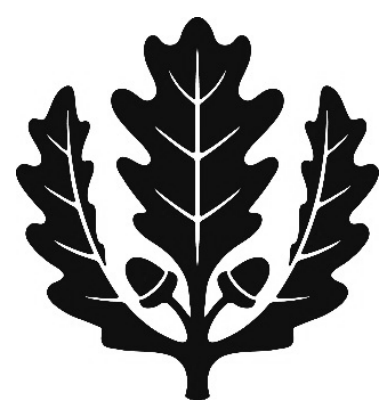




\title{
Connecting the Rule of Recognition and Intentionalist Interpretation: An Essay in Honor of Richard Kay
}

\author{
LARRY ALEXANDER *
}

\section{INTRODUCTION}

It is an honor and a pleasure to participate in this celebration of the career of Richard Kay. Rick and I go way back. And although we live at opposite ends of this continental country, the distance between our views on the topics of our mutual interest is, if it exists, microscopic. Or at least that is how I understand Rick's views.

The two areas of Rick's interest and mine that I shall address are the foundations of legal systems and legal interpretation as a quest for lawmakers' intended meanings. Rick has written extensively about both topics. ${ }^{1}$ I have written extensively about the second but much less about the first. $^{2}$ What neither of us has written about explicitly, however, is what, if

\footnotetext{
* Warren Distinguished Professor, University of San Diego School of Law. I want to thank Jim Allan and Steve Smith for their comments, and Joe Bsaibes and Noah Gaarder-Feingold for their excellent research assistance.

${ }^{1}$ For Kay's work on the foundations of legal systems, see RICHARD S. KAY, THE GLORIOUS Revolution And the CONTINUITy of LAW (2014); Richard S. Kay, Constituent Authority, 59 AM. J. COMP. L. 715 (2011); Richard S. Kay, Constitutional Chrononomy, 13 RATIO JURIS. 31 (2000); Richard S. Kay, William III and the Legalist Revolution, 32 CONN. L. REV. 1645 (2000); Richard S. Kay, The Illegality of the Constitution, 4 Const. Comment. 57 (1987); Richard S. Kay, Preconstitutional Rules, 42 OHIO ST. L.J. 187 (1981). For Kay's work on legal and especially constitutional interpretation, see Richard S. Kay, Construction, Originalist Interpretation and the Complete Constitution, 19 U. PA. J. CONST. L. OnLINE 1 (2017); Richard S. Kay, Original Intention and Public Meaning in Constitutional Interpretation, 103 Nw. U. L. REV. 703 (2009); Richard S. Kay, “Originalist" Values and Constitutional Interpretation, 19 HARV. J.L. \& PUB. POL'Y 335 (1996); William B. Fisch \& Richard S. Kay, The Legitimacy of the Constitutional Judge and Theories of Interpretation in the United States, 42 AM. J. CoMP. L. 517 (1994); Richard S. Kay, Original Intentions, Standard Meanings, and the Legal Character of the Constitution, 6 CONST. COMMENT. 39 (1989); Richard S. Kay, Adherence to the Original Intentions in Constitutional Adjudication: Three Objections and Responses, 82 Nw. U. L. REV. 226 (1988).

${ }^{2}$ LARRY ALEXANDER \& EMILY SHERWIN, DEMYSTIFYING LEGAl REASONING chs. 5-6 (2008); LARry AleXANDER \& EMILy SHERWIN, The Rule of Rules: Morality Rules, PRINCIPLES, AND THE DILEMMAS OF LAW ch. 5 (2001); Larry Alexander, Goldsworthy on Interpretation of Statutes and Constitutions: Public Meaning, Intended Meaning and the Bogey of Aggregation, in LAW UNDER A DEMOCRATIC CONSTITUTION: ESSAYS IN HONOUR OF JEFFREY GOLDSWORTHY (Lisa Burton Crawford et al. eds., 2019); Larry Alexander, Law and Politics: What is Their Relation?, 41 HARV. J.L. \& PUB. POL'Y 355 (2019); Lawrence A. Alexander, Was Dworkin an Originalist?, in THE LEGACY OF RONALD DWORKIN 299 (Wil Waluchow \& Stefan Sciaraffa eds., 2016); Larry Alexander, Legal Positivism and Originalist Interpretation, 16 REVISTA ARG. DE TEORIA JURIDICA (2015); Larry Alexander, Hart and Punishment for Negligence, in HART ON RESPONSIBILITY (Christopher G. Pulman ed., 2014); Larry
} 
any, is the connection between these two topics. That connection is what I shall try to establish here.

\section{KAY ON THE FOUNDATION OF LEGAL SYSTEMS}

The article that first acquainted me with Rick the scholar was his 1981 piece Preconstitutional Rules, ${ }^{3}$ which appeared in a symposium issue of the Ohio State Law Journal in which I also contributed a piece. ${ }^{4}$ In Rick's piece, he points out that the U.S. Constitution is the touchstone of legal validity in the U.S. legal system only because of something more fundamental than the Constitution-what Rick calls a "preconstitutional rule." Rick's notion of a preconstitutional rule is, as Rick acknowledges, ${ }^{5}$ equivalent to what H. L. A. Hart called a "rule of recognition" 6 in The Concept of Law. ${ }^{7}$

Rick points out that constitutional decisions can be criticized as inconsistent with the preconstitutional rule. A decision that misinterprets the Constitution but does not question the preconstitutional rule that establishes the Constitution as fundamental law is obviously criticizable as legally erroneous. ${ }^{8}$ But one can also criticize the preconstitutional rule itself, not on legal grounds-for it is the foundation of the legal system-but

Alexander, Constitutional Theories: A Taxonomy and (Implicit) Critique, 51 SAN DIEGO L. REV. 623 (2014); Larry Alexander, Originalism, the Why and the What, 82 FORDHAM L. REV. 539 (2013); Larry Alexander, Simple-Minded Originalism, in THE Challenge OF ORIGINALISM: THEORIES OF CONSTITUTIONAL INTERPRETATION 87 (Grant Huscroft \& Bradley W. Miller eds., 2011); Larry Alexander, Telepathic Law, 27 CONST. COMMENT. 139 (2010); Larry Alexander, Waluchow's-Living Tree Constitutionalism, 29 LAW \& PHIL. 93 (2009); Larry Alexander, Of Living Trees and Dead Hands: The Interpretation of Constitutions and Constitutional Rights, 22 CANADIAN J.L. \& JURIS. 227 (2009); Larry Alexander \& Frederick Schauer, Rules of Recognition, Constitutional Controversies, and the Dizzying Dependence of Law on Acceptance, in THE RUlE of RECOGNITION AND THE U.S. CONSTITUTION 175 (Matthew D. Adler \& Kenneth Einar Himma eds., 2009); Larry Alexander, How to Understand Legislatures: A Comment on Boudreau, Lupia, McCubbins, and Rodriguez, 44 SAN DIEGO L. REV. 993 (2007); Larry Alexander \& Saikrishna Prakash, "Is That English You're Speaking?” Why Intention Free Interpretation Is an Impossibility, 41 SAN DIEGO L. REV. 967 (2004); Larry Alexander \& Emily Sherwin, Interpreting Rules: The Nature and Limits of Inchoate Intentions, in LEGAL INTERPRETATION IN DEMOCRATIC STATES 3 (Jeffrey Goldsworthy \& Tom Campbell eds., 2002); Larry Alexander, On Statutory Interpretation: Fancy Theories of Interpretation Aren't, 73 WASH. U. L. Q. 1081 (1995); Larry Alexander, Originalism, or Who is Fred?, 19 HARV. J.L. \& PUB. POL'Y 321 (1995); Larry Alexander, All of Nothing at All? The Intentions of Authorities and the Authority of Intentions, in LAW AND INTERPRETATIONS: ESSAYS IN LEGAL PHILOSOPHY 357 (Andrei Marmor ed., 1995).

${ }^{3}$ Kay, Preconstitutional Rules, supra note 1, at 187.

${ }^{4}$ Larry A. Alexander, Modern Equal Protection Theories: A Metatheoretical Taxonomy and Critique, 42 OHIO ST. L.J. 3 (1981).

5 See Kay, Preconstitutional Rules, supra note 1, at 189-90 (discussing Hart's "rule of recognition").

${ }^{6} I d$. at $100-02$.

${ }^{7}$ H. L. A. HART, The CONCEPT OF LAW (1961).

${ }^{8}$ Kay, Preconstitutional Rules, supra note 1, at 190. 
on moral or prudential grounds. ${ }^{9}$ Why, for example, should we be bound by legal norms established over 200 years ago by privileged white males, some of whom owned slaves? Why should the preconstitutional rule, the rule of recognition, recognize their constitution as fundamental law rather than some other possible constitution more apt for the country and world we inhabit today?

Rick notes that there are also two non-evaluative questions we can ask about the preconstitutional rule. We can ask what is the preconstitutional rule-what does it prescribe (its content)-and we can ask whose say so determines what it is. ${ }^{10}$ Rick takes as a given in the article that the answer to the latter question is that it is the Supreme Court's understanding of the preconstitutional rule that counts. ${ }^{11}$ In this respect, Rick is following Hart, who argued that the rule of recognition is established by its acceptance as such by officials. ${ }^{12}$

Here I want to pause. There is an obvious bootstrap quality in Hart's claim that rules of recognition are established by virtue of their acceptance by officials. For what makes officials official? Being an official is not something bestowed by nature, like being female or being over six feet tall. One is an official because one meets criteria established by law. But the law that makes one an official is law because it is valid within a legal system, which in turn rests on a rule of recognition, which in turn, according to Hart, exists because of acceptance by officials. ${ }^{13}$ In other words, one is an official by virtue of accepting the system that makes one an official. Nice work if you can get it.

Obviously, then, there has to be more than official acceptance to establish a rule of recognition. Alfred's accepting a rule of recognition that recognizes as a legal norm "Alfred is an official" will not by itself make Alfred's rule of recognition the rule of recognition. There has to be something else.

For Hart, that something else was efficacy. ${ }^{14}$ That is, the people in whose society the rule of recognition exists must generally comply with the laws validated by that rule of recognition. Of course, people comply with law to varying degrees and for all sorts of reasons. And they may comply without accepting as valid the laws the officials' rule of recognition validates. Indeed, on the Hartian model, which Rick accepts, there may be more than one legal system purporting to govern a society.

\footnotetext{
${ }^{9} \mathrm{Id}$.

${ }^{10}$ See id.

${ }^{11}$ See id. at $190-91$

${ }^{12}$ HART, supra note 7 , at 113.

${ }^{13}$ See Alexander \& Schauer, supra note 2, at 178-79. See also Richard H. FALLON, JR., LAW AND LEGITIMACY IN THE SUPREME COURT 107-09 (2018).

${ }^{14}$ HART, supra note 7, at 113.
} 
French citizens in World War II may have divided over whether the laws of the Vichy government or the laws of the Free French government in exile should be obeyed when they conflicted. ${ }^{15}$ And if they divided over which laws to accept as valid, they perforce divided over who were really "officials." 16

So, if, as Hart believed and as Rick and I believe, the content of the rule of recognition is an empirical question, it is a complex, messy, difficult empirical question. It will be a function, not just of the attitudes of a discrete group of officials, who are only officials because of their attitudes, but of the attitudes and beliefs of a much wider population. As I have said elsewhere, determining the content of the rule of recognition is perhaps the most difficult jurisprudential question for jurisprudes. ${ }^{17}$

One consequence of the possibility of competing rules of recognition and thus competing legal systems within a single society is of relevance to us Americans today. Matthew Adler has pointed out that because legal actors from the Supreme Court Justices on down disagree about what makes a constitutional decision correct-what are the "truthmakers" of constitutional decisions - such a fundamental disagreement seems to entail that we lack a unified legal system and in a real sense lack law. Adler asks, "What would it take for one side in this debate to be [legally] correct and the other [legally] incorrect? How is that even possible given the very fact of debate?"18

I shall come back to Adler's question later when I turn to Rick's account of proper constitutional interpretation. For there is a link between the methodologies of constitutional interpretation and the content of the rule of recognition.

Kay goes on to point out several interesting aspects of preconstitutional rules. He distinguishes arguments that assume a certain such rule and thus that count as legal arguments from arguments about the desirability of this or that preconstitutional rule. The latter arguments cannot be legal arguments because what is legal depends upon the acceptance of a given preconstitutional rule. ${ }^{19}$ Kay also distinguishes "closed" and "open" preconstitutional rules. The latter leave open certain

\footnotetext{
${ }^{15}$ René Cassin, Vichy or Free France?, 20 FOREIGN AFF. 102, 107-08 (1941).

${ }^{16}$ See Alexander \& Schauer, supra note 2, at 178 n.16.

17 See Alexander, Constitutional Theories, supra note 2, at 641-43. See also Alexander \& Schauer, supra note 2, at 186-87.

${ }^{18}$ Matthew D. Adler, Interpretive Contestation and Legal Correctness, 53 WM. \& MARY L. REV. 1115, 1136 (2012). See also Matthew D. Adler, Popular Constitutionalism and the Rule of Recognition: Whose Practices Ground U.S. Law?, 100 Nw. U. L. REV. 719, 804-05 (2006). If we restrict ourselves to officialism, the answer to Adler's question is that officials accept that whatever the Supreme Court decides is constitutional law is constitutional law. See Alexander, Who is Fred, supra note 2, at 326 n.17. Until the Court decides, however, there is no shared constitutional law. See also Alexander \& Schauer, supra note 2, at 184-86.

${ }^{19}$ Kay, Preconstitutional Rules, supra note 1, at 193.
} 
issues of validity - issues that can be resolved in the future. ${ }^{20} \mathrm{He}$ quotes Marbury v. Madison ${ }^{21}$ for an illustration of reliance on a closed preconstitutional rule, one in which the Constitution is to be understood as its authors intended it to be understood, which he says remains orthodox constitutional theory. ${ }^{22}$ And he contrasts this closed preconstitutional rule with the open one, a clear manifesto of juristocracy: "Properly promulgated government actions are valid if the Supreme Court does not disapprove them." ${ }^{23}$ (Query: How on such a preconstitutional rule do we know in the absence of Supreme Court decisions what things are "government actions," or when they are "properly promulgated"? And is the Supreme Court then only the Supreme Court because it tells us so? $)^{24}$ The choice between a closed and an open preconstitutional rule is a choice between fixity and flexibility; but it is also a choice between decision makers - the authors of the Constitution or the Supreme Court.

Rick continued his discussion of preconstitutional rules in an article published six years after Preconstitutional Rules entitled The Illegality of the Constitution. ${ }^{25}$ In it, Rick illustrates the nature of rules of recognition by recounting how the United States went from being governed by the Articles of Confederation to being governed by the Constitution. The preconstitutional rule that legitimated the Articles, and acts legitimated by the Articles, did not validate the work of the constitutional convention and its proposed Constitution. ${ }^{26}$ The latter would only be legitimated by a different preconstitutional rule. And the argument for accepting a new preconstitutional rule, one that would legitimize the Constitution, could not be legal; for legal arguments are offered within whatever legal system the preconstitutional rule legitimizes and cannot be deployed to support preconstitutional rules themselves. ${ }^{27}$ The arguments for accepting a preconstitutional rule must be extra-legal, that is political and moral. ${ }^{28}$ Ordinary legislative bodies also could not effect a change of preconstitutional rules, as they themselves are constituted under the existing preconstitutional rule and might have a different character and different powers under a new preconstitutional rule. ${ }^{29}$ Ultimately, the

\footnotetext{
${ }^{20}$ Id. at 195.

${ }^{21} 5$ U.S. 137, 176-79 (1803).

${ }^{22}$ Kay, Preconstitutional Rules, supra note 1, at 195-96. I agree with Kay that the position taken in Marbury remains orthodox constitutional theory, and in the concluding section of this Essay I will explain why that is so.

${ }^{23} I d$. at 197.

${ }^{24}$ See Stephen E. Sachs, The Law and Morals of Interpretation, 13 DukE J. CONST. L. \& PuB. POL'Y 103, 105 (2018)

${ }^{25}$ Kay, Illegality, supra note 1.

${ }^{26} \mathrm{Id}$. at 67.

${ }^{27} \mathrm{Id}$. at 70

${ }^{28} \mathrm{Id}$. at $70-77$.

${ }^{29} \mathrm{Id}$. at 72 .
} 
ratifying conventions and popular acceptance of the new regime over time legitimated the preconstitutional rule that recognized the Constitution as supreme law. ${ }^{30}$

Thus, the emergence of a new preconstitutional rule is a revolution, a change of regimes, the establishment of a new legal order. ${ }^{31}$ Rick concludes as follows:

The main point to be learned from an examination of the beginnings of the Constitution, is not the fitness of one or another preconstitutional rule. On the contrary, it shows that we cannot settle on a correct position in this regard as a matter of law or logic. The creation of, or change in, the preconstitutional rule will reflect the needs and values of the time in which it is effective and will draw its legitimacy from its conformity with those needs and values. And since that legitimacy is always a current matter, any preconstitutional rule is always provisional, subject to change when social and political factors require it. The great change of 1787-89 was obvious because it involved an alteration of both the preconstitutional rule and formal accoutrements of that rule, the Articles of Confederation and the institutions of government created under it. Similar changes which leave the formal aspects of the legal system untouched may not command our attention in the same way but they surely occur. It is the possibility of such changes that makes sensible our continuing discussion about constitutional fundamentals. In this respect we are always in a situation like the one that confronted the founders in 1787-89. ${ }^{32}$

Rick's conception of preconstitutional rules, the rules that legitimate legal regimes, and thus the statues of officials within them, is that they exist by virtue of their broad acceptance by the governed, not by virtue of acceptance solely by officials. For, as pointed out, officials are such only because the legal regime in question deems them to be, and their bootstrapping acceptance of that regime cannot legitimize it in the absence of much broader social acceptance. And when the legal regime is no longer accepted as legitimate by enough people, then the legitimating preconstitutional rule, the rule of recognition, no longer exists, even if it is still accepted by officials of the old regime. In such circumstances, the society has entered a revolutionary period, one in which the content of the

\footnotetext{
${ }^{30}$ Id. at 72-73. See id. at 77-79; Alexander and Schauer, supra note 2, at 180-81.

${ }^{31}$ Kay, Illegality, supra note 1 , at 61 .

${ }^{32} \mathrm{Id}$. at 80 (footnote omitted).
} 
preconstitutional rule is now up for grabs, and in which it is possible that different legal regimes will purport to govern the same society.

Rick calls the authority of constitution makers that is derived from a preconstitutional rule accepted by the people "constituent authority." $33 \mathrm{He}$ has written a lot about constituent authority, distinguishing constitutions that were effectively created legally, that is, under the rules of a legal regime that continued to exist but no longer governed the polity under the new constitution, from constitutions that were the products of revolutions. The latter resulted from changes in the preconstitutional rules and replaced one legal regime with another. The U.S. Constitution was, as mentioned, a revolutionary constitution and replaced the Articles of Confederation without being organically derived from the Articles.

Rick's article Constituent Authority is a study of constitutional changes, revolutionary or not, in a multitude of countries. ${ }^{34}$ But the constitutional change that intrigued him as much as the revolutionary one that produced the U.S. Constitution was the English Revolution of 1688-89, which was illegal under the extant legal regime, but during which the participants went to great lengths to deny its illegality. ${ }^{35}$ As Rick puts it:

Every new regime must conform to critical social and political values in the population it intends to govern. Sometimes, however, a core value in such a society is the value of legality itself. When that is the case we can expect the kind of paradoxical appeal to legality illustrated by the Revolution of $1688-89$.

In 1688 Britain, the political nation was law-saturated . . . . How, in such an environment, can one make a revolution? The answer, as the remarkably successful results of 1688-89 testify, is very carefully. At every point the departures from law were minimized and disguised. William III, as much as any of his subjects, understood the necessity for this approach. $^{36}$

\section{KAY ON CONSTITUTIONAL INTERPRETATION}

Rick belongs to that small but righteous group of scholars who endorse original intended meaning as the proper quarry of constitutional interpretation (and, indeed, of legal interpretation more generally). That

\footnotetext{
${ }^{33}$ See Kay, Constituent Authority, supra note 1, at 716.

${ }^{34} I d$.

${ }^{35}$ See KAY, GlORIOUS, supra note 1, at I; Kay, William III, supra note 1, at 1645-47.

${ }^{36} \mathrm{Kay}$, William III, supra note 1, at 1664.
} 
group includes, to my knowledge, in addition to Rick, Stanley Fish, ${ }^{37}$ Steven Knapp, ${ }^{38}$ Walter Benn Michaels, ${ }^{39}$ Stephen Neale, ${ }^{40}$ Saikrishna Prakash, ${ }^{41}$ Scott Soames, ${ }^{42}$ and myself. ${ }^{43}$ (I would add Richard Ekins to the list were he an American interested in constitutional interpretation, as his view of statutory interpretation is identical to the view of those listed above. $^{44}$ )

Original intended meaning (OIM) originalists are a tiny branch of the much larger camp of constitutional originalists, the rest of whom now call themselves original public meaning (OPM) originalists. I have written that there is likely no difference between these groups because the hypothetical reasonable interpreter at the time the Constitution was promulgated-the construct used by OPM originalists - would himself be seeking the original intended meaning. ${ }^{45}$ Moreover, the problem of aggregating intended meanings in group authored documents like the Constitution will dog the OPM originalists to the same extent as it dogs OIM originalists such as Rick and me.

Rick's adherence to OIM in constitutional interpretation is longstanding and well documented. ${ }^{46}$ Mine in print goes back to $1995 .{ }^{47} \mathrm{I}$ shall explain my views on interpretation briefly, views that I believe Rick shares jot and tittle.

I begin with the nature of texts. A text, as I shall be using the term, is a set of symbols - of any kind - that is meant by its producer - the author(s) to communicate a message to the intended audience. The symbols used can be marks, sounds, dots and dashes, smoke, flags, pictures - indeed, anything can be used as symbols capable of conveying messages. And although we are usually interested in the actual authors of a text, texts produced by one author can be appropriated by another author to convey the same or a different message. And one can meaningfully ask what

${ }^{37}$ See, e.g., Stanley Fish, There Is No Textualist Position, 42 SAN DIEGo L. REV. 629, 632-33 (2005).

${ }^{38}$ See, e.g., Steven Knapp \& Walter Benn Michaels, Not a Matter of Interpretation, 42 SAN DIEGO L. REV. 651, 655 (2005).

${ }^{39}$ See, e.g., id.; Walter Benn Michaels, The Fate of the Constitution, 61 TEX. L. REV. 765, 773 (1982).

${ }^{40}$ See, e.g., Stephen Neale, Convergentism and the Nature of Law 1, 1, 5 (Mar. 14, 2013) (unpublished draft).

${ }^{41}$ See, e.g., Alexander \& Prakash, supra note 2, at 2.

${ }^{42}$ See, e.g., Scott Soames, Toward a Theory of Legal Interpretation, 6 N.Y.U. J.L. \& LIBERTY 231, 241 (2011)

${ }^{43}$ See publications listed in note 2

${ }^{44}$ See, e.g., RichaRd EKINS, The NATURE OF LEgISLATIVE INTENT 1-2 (2012).

${ }^{45}$ Alexander, Goldsworthy, supra note 2, at 8-11.

${ }^{46}$ For articles showing Kay's adherence to OIM in constitutional interpretation, see publications listed in note 1 .

${ }^{47}$ Alexander, All or Nothing at All, supra note 2. 
message a text would convey if it had been produced, not by its actual author, but by some different author.

If there is no author - no person who produced the marks, sounds, etc. in order to convey a message - then we do not have a text. ${ }^{48}$ The marks, sounds, etc. may be a sign of something, much as smoke is a sign of fire, or geese flying south are a sign that winter is coming. ${ }^{49}$ Marks that might look like symbols, when we understand they are not - think of cloud formations that resemble the letters $\mathrm{C}-\mathrm{A}-\mathrm{T}$-render certain questions nonsensical that would make sense were there an author. (Consider: Are the clouds speaking English or French? Are they referring to all felines or only to tabby cats?) Even when there is an author and a text, the text may be a sign of something other than the message conveyed. For example, the text may be a sign that the author has poor handwriting or can use word processing. Or its message may be a sign that the author was angry, or agitated, or in love.

Texts are individuated by the messages that their authors are intending to convey thereby. That is why the text of the U.S. Constitution in Spanish can be the same as its text in English, or why its text in one font can be the same as its text in a different font. Even though those tokens of the text differ from one another, they are tokens of the same text if the message they convey is the same. ${ }^{50}$

${ }^{48}$ Alexander \& Prakash, supra note 2, at 976; Michaels, supra note 39, at 774.

${ }^{49}$ For a similar point, see Kay, Original Intentions, supra note 1, at 40-41.

${ }^{50} \mathrm{Id}$. This point is quite important but always overlooked by those who argue for interpreting a text differently from its authors' intended meaning but who also claim that they are not changing the text - what some call "informal amendment." They overlook this point because they are misled by the fact that many words or phrases in a given language can bear more than one meaning in that language. (In truth, when words or phrases are decoupled from the meanings their authors intended, there is no limit to the meanings they can bear; any symbol can symbolize anything its author intends.) But when the text in question is translated into a different language, one in which the authors' intended meaning is expressed in words or phrases different from those that express the new meaning, then the translated text with the new meanings will not be the same as the original text with the authors' intended meanings. In other words, if word or phrase X can mean either A or B in conventional English, and the authors' meaning A is changed to B, then even though the English text would remain the same (X), its translation into another language might change the text from $\mathrm{Y}$ to $\mathrm{Z}$. So what appears in one language to be an unamended text will appear in another language to be an amended one. Alexander \& Schauer, supra note 2, at 183-84 n.31. Informal amendment will therefore be shown to have been a formal one after all. And this is why "interpreting" the text to achieve some value rather than to retrieve authorial intended meaning is not interpretation but amendment by those without authority to amend. When Joseph Raz advocates "interpretations" that "improve" a constitution, he is blessing unauthorized amendments rather than interpretations. JOSEPH RAZ, BETWEEN AUTHORITY AND INTERPRETATION: ON THE THEORY OF LAW AND PRACTICAL REASON 354, 361 (2009). Likewise, when Justice Breyer urges courts to "interpret" the Constitution to achieve "active liberty," he is advocating constitutional amendments by the judiciary. STEPHEN BREYER, ACTIVE LIBERTY: INTERPRETING OUR DEMOCRATIC CONSTITUTION 21-34 (2005). He is misled by the symbols remaining the same after such an "interpretation." 
When our interest is in the actual authors of a text and the message that they intended to convey thereby, we are acting as "originalists." If we are unsure of the meaning of some word in the text, then, given that our interest is in the message that the actual authors intended to convey, we will consult dictionaries contemporaneous with their authoring, not later dictionaries. And when their words produce an ambiguity, to resolve it we will ask about the context in which they were authoring, not about contexts that post or pre-date their authoring.

The 'conventional meanings' of words - what meaning dictionaries would assign them - are merely the meanings most people at a particular time, and in a particular locale, would intend to convey by those words. These meanings are therefore time and place bound and can, and do, change over time and from place to place. But authors may and often do employ unconventional meanings. They may use codes, or idiolects, or malapropisms. If their intended audience understands the code or the idiolect that they are employing, or recognises the malapropism and its actual intended referent, then the authors can be successful in conveying their message to their intended audience. If one is interested in knowing what message the authors are intending to convey, one will want to know what code, idiolect, etc. the author is employing.

Authors rely on implicatures and implicitures in conveying their intended messages. They often mean more, and sometimes less, than they actually say. "John and Mary are married," uttered when they are observed walking together, usually conveys the message that they are married to each other. "It is an aggravating circumstance to use a gun in the commission of a crime" usually conveys the message that it is aggravating when the gun is used as a weapon but not as an item of barter for illegal drugs.

Turning now from interpretation generally to the interpretation of legal texts, in whomever the authority to exact legal norms resides - in constitutional ratifiers, in legislatures, in administrators, in judges - then when they decide which norms to enact and attempt to communicate those norms through a written or oral text, the job of the intended audience is to figure out what norms the authors enacted and intended to communicate. If the audience chooses legal norms that differ from those which the authors chose to enact and communicate, the authority of the authors is undermined. Only originalism is authority preserving. Any departure from originalism either transfers authority from the authors to someone elsefor example, to judges - or to some mindless process, such as the process by which the meanings of words change over time, as would occur if contemporary dictionary meanings rather than the meanings contemporaneous with authorship were relied on in 'interpreting' legal texts. 
Interpretation of legal texts is an empirical, not a normative, endeavor. The interpreter wants to know what norm the authorities intended to communicate through their text. It is often quite difficult to answer the interpreter's question. The authorities may have expressed their intended norm poorly. Or the text may be old or ambiguous, and the context of its promulgation unclear or unknown. But however difficult interpretation may be, it is unavoidable if the norms that we are to be governed by are the norms intended by those with authority to govern us.

Finally, interpretation of legal texts must deal with the fact that some legal authorities are multi-member bodies and sometimes bicameral multi-member bodies, and can only enact legal norms with the concurrence of majorities or super-majorities. What is the intended meaning of a legal text when the members who voted to enact it did not intend to convey the same meanings and hence the same norms by it? This is the aggregation problem. On my view, it cannot be avoided. And when there is no shared meaning that the requisite number of norm enactors endorse, then the text they enact is legal gibberish. It is a composite of different intended norms that cannot be combined into a single norm. Perhaps that unfortunate result is rare. Perhaps it can be avoided by having those who vote for the text accept the meaning intended by some person or committee without having that meaning in mind themselves. I see no way, however, to make the aggregation problem disappear without at the same time undermining the authority of those who are supposed to possess it. ${ }^{51}$

As I read Rick's copious writings on the topic, he would agree with everything I have said. It is worth quoting a passage from one of Rick's earliest articles on constitutional interpretation:

The Constitution became supreme law as a result of the regard in which its rules and the process for making those rules were held at the time of its promulgation - that is as a consequence of a widely shared political understanding as to the sources and limits of lawmaking power. Put too simply, the sequence of the drafting and ratification of the Constitution was understood to express the will of "the people" in as clear a way as the institutions and traditions of that time permitted. And it was a political axiom of that day that all laws and constitutions were subject to revision or replacement by the sovereign people. The critical point for my purposes is that the Constitution as law cannot

${ }^{51}$ The preceding discussion is similarly stated and examined further in Alexander, Goldsworthy, supra note 2, at 5-8. For Professor Kay's shared view of the aggregation problem, see Richard S. Kay, American Constitutionalism, in CONSTITUTIONALisM: PhilosophiCAL Foundations 35-36 (Larry Alexander ed., 1998). 
materialize out of the air. We come to regard certain language as the Constitution because of something about the way it was uttered. Who can disagree with Walter Benn Michaels that "[n]o one would even try to interpret the Constitution if everyone thought it had been put together by a tribe of monkeys with quills."

It is my position, therefore, that interpretation of the Constitution consistently with the intentions of its enactors is inseparable from a determination to treat the Constitution as law. ${ }^{52}$

\section{CONNECTING THE PRECONSTITUTIONAL RULE WITH CONSTITUTIONAL INTERPRETATION}

Some have expressed the theory that in the United States, given differences in the way Justices of the Supreme Court, other judges and lawyers, and ordinary people interpret the Constitution, the conclusion to be drawn is that we lack a single preconstitutional rule. Instead, the reality is that we have several dueling preconstitutional rules, each recognizing a somewhat different legal system, and each purporting to be the legal system of the United States. ${ }^{53}$

I think this concern is overblown. All federal officials, including Justices of the Supreme Court, recognize that they owe their official status to language in the 1789 Constitution and its original intended meaning. Moreover, officialdom accepts that Supreme Court constitutional decisions are to be treated within the legal system as if they are correct interpretations of the Constitution, even if they are otherwise regarded as misinterpretations. ${ }^{54}$ Finally, no justice or judge to my knowledge has ever asserted that he or she is not bound to adhere to the 1789 Constitution and its formal amendments, at least in the absence of a Supreme Court precedent that is viewed as erroneous but has yet to be overruled by the Court. $^{55}$

The source of the worry that we have a multitude of competing legal systems stems from assuming differing approaches to interpretation of the Constitution - originalism, textualism, and non-originalist, non-textualist approaches of varying types - are not just correct and incorrect ways to interpret the Constitution. For what is the Constitution to which everyone,

\footnotetext{
${ }^{52}$ Kay, Original Intentions, supra note 1, at 45 (footnotes omitted) (quoting Michaels, supra note 39 , at 774$)$.

${ }^{53}$ See Adler, Interpretive Contestation, supra note 18, at 1119; Adler, Popular Constitutionalism, supra note 18 , at 719-20.

${ }^{54}$ See Alexander, Who is Fred?, supra note 2, at 326 n.17.

${ }^{55}$ See, e.g., William Baude, Is Originalism Our Law?, 115 ColuM. L. ReV. 2349, 2359 (2015).
} 
originalists and others, swears fealty? It cannot be the parchment in the National Archives, with its various markings. Take away its authors and the meanings they intended to convey, and that piece of parchment and its markings could mean anything or nothing at all. For suppose we discovered it was produced by "monkeys with quills," ink spill. We would not anguish over the meaning of the marks because they would have no meaning. Mere marks cannot declare that they are a language, much less what language they are. We know the marks on the parchment are English, and American English of the late eighteenth century rather than modern English, Australian English, South African English, a special subculture's dialect, or a Russian code masking as English. We know this because we know who its authors are and what they were about in producing this piece of parchment. But ignore their intended meanings, and that piece of parchment and its markings could mean anything or nothing.

That is why Rick and I believe originalism of the intended meaning variety is the only game in town if one purports to be interpreting the Constitution - that is, the Constitution to which everyone, high or low, claims to swear allegiance. Our situation is not one where we have different competing constitutions recognized by different preconstitutional rules. Rather, we have a single preconstitutional rule that recognizes the Constitution of 1789 as fundamental law but simultaneously massive confusion about the implications for interpretation of that recognition. For the Constitution of 1789 is nothing other than its authors' intended meanings - meanings that will remain the same no matter the language in which they are expressed.

I have argued that the courts do regard the Constitution of 1789 and its formal amendments as fundamental law; that is their preconstitutional rule, and decisions that give the opposite impression are the product of judicial confusion regarding what it means to interpret the Constitution faithfully. But beyond officialdom, those whom Hart believed counted for identifying the rule of recognition, what does society at large believe is the preconstitutional rule? Of course, ordinary people — and even most judges and lawyers - don't think about law in such terms. But Hart notwithstanding, the views of the people - the ruled - should count, at least if the officials of interest to Hart are to be regarded as legitimate and not just a gang imposing its will by force, whatever their internal point of view of their own rules' legitimacy.

I would hazard a guess that the vast majority of people assent to the courts' constitutional decisions, not because they like all the results, but because they believe the justices and judges are attempting in good faith to

\footnotetext{
${ }^{56}$ Kay, Original Intentions, supra note 1, at 45 (quoting Michaels, supra note 39, at 774).
} 
apply the Constitution - the Constitution of 1789 and its formal amendments - and that, were they aware that the justices and judges were not doing this, but were instead making up rules and falsely declaring that these were based on the Constitution of 1789, the courts would lose their legitimacy in the eyes of the public. ${ }^{57}$

And why, finally, should we follow the intended meanings of imperfect and unrepresentative persons from a time far different in many respects from our own? Surely, the Constitution they bequeathed us is defective in all sorts of ways. ${ }^{58}$ So why follow it?

The answer has to be that, whatever its imperfections, the Constitution of 1789 is preferable to the alternatives. It settles matters that must be settled, and there is no alternative constitution around which we can all rally. There is no prospect of a bloodless coup in which the preconstitutional rule that recognizes the Constitution of 1789 is replaced by a different preconstitutional rule recognizing some other constitution or juristocracy.

${ }^{57}$ See Alexander, Constitutional Theories, supra note 2, at 641-43.

58 See, e.g., SANFord LEVINSON, OUR Undemocratic CONSTITUTION: Where the Constitution Goes Wrong (And How We the People Can Correct It) 11 (2006). 